\title{
Simbol Illuminati dalam Video Klip
}

\section{Winda Yunita Lestari ${ }^{1}$ dan Freddy Yusanto ${ }^{2}$}

\author{
${ }^{1,2}$ Program Studi Ilmu Komunikasi, Fakultas Komunikasi dan Bisnis, \\ Universitas Telkom, Bandung
}

\begin{abstract}
ABSTRAK
Illuminati merupakan kelompok elit yang memiliki pertalian darah dan memiliki tujuan untuk mengalihkan manusia dari jalan Tuhan dan menaklukkan manusia dengan cara-cara yang canggih untuk mengendalikan pikiran (yaitu media massa, pendidikan, kebebasan seksual, migrasi, keberagaman, dll). Salah satu strateginya adalah penghancuran agama-agama besar diseluruh dunia, peruntuhan monarki dan pemerintahan yang teratur, penghilangan patriotisme bangsa, penghapusan dan penguasaan terhadap ikatan keluarga. Salah satu penyanyi berkebangsaan Amerika Serikat bernama Kesha Rose Sebert atau dikenal dengan nama panggung Ke\$ha sengaja memasukkan unsur simbol-simbol Illuminati di dalam video klip-nya yang berjudul Die Young. Video klip ini mendapat perhatian lebih dari 138 juta viewers dan 3,4 Juta subscribe di seluruh dunia. Penelitian kualitatif ini menggunakan pendekatan semiotika John Fiske. Teknik analisis data dilakukan berdasarkan teori yang dikemukakan oleh John Fiske melalui kode-kode televisi yang terbagi ke dalam tiga level, yaitu level realitas, level representasi dan level ideologi. Penelitian ini bertujuan untuk membongkar pemaknaan simbol-simbol Illuminati dalam video klip "Die Young". Hasil penelitian pada level realitas, menunjukkan bahwa Ke\$ha mencoba untuk mendekatkan diri pada penonton dengan memperlihatkan bentukbentuk simbol tersebut, ia mencoba untuk mengagungkan dan meninggikan simbol-simbol iluminati yang ada di video klip ini. Pada level representasi, simbol Illuminati digambarkan melalui penonjolan-penonjolan pada simbol iluminati agar lebih eye catchy, sehingga penonton bias merasakan kedekatan, dengan cara memunculkan simbol Illuminati sebagai bagian dari kekuatan, misteri dan keseriusan dalam kehidupan manusia. Sedangkan pada level ideologi, dapat disimpulkan bahwa kebebasan gaya hidup, sensualitas, anti kemapanan menjadi hak dari setiap individu dan mereka berhak untuk melakukan apapun yang mereka inginkan
\end{abstract}

Kata-kata Kunci: Kajian film; semiotik film; kajian televisi; semiotik televisi; video klip

\section{ABSTRACT}

Illuminati Symbol in Video Clip

The Illuminati are an elite group that has blood ties and has a goal to divert humans from the path of God and conquer humans in sophisticated ways to control the mind (ie mass media, education, sexual freedom, migration, diversity, etc.). One of their strategy is the destruction of major religions throughout the world, the collapse of monarchy and regular government, the elimination of national patriotism, and the elimination and control of family ties. One of the American singers named Kesha Rose Sebert, known as the stage name Ke\$ha, intentionally included elements of the Illuminati in his video clip entitled "Die Young". This video clip received the attention of more than 138 million viewers and 3.4 million subscribed worldwide. This qualitative study uses the semiotic method of John Fiske. The data analysis technique is based on the theory put forward by John Fiske through television codes which are divided into three levels, namely the level of reality, the level of representation and the level of ideology. This study aims to dismantle the meaning of Illuminati symbols in the "Die Young" video clip. The results of the research at the level of reality, show that Ke\$ha tries to get closer to the audience by showing these symbolic forms, he tries to glorify and elevate the illuminative symbols in this video clip. At the level of representation, the Illuminati symbol is portrayed through protrusions on the illuminati symbol to make it more eye-catching, so that the audience can feel closeness, by raising the Illuminati symbol as part of strength, mystery and seriousness in human life. While at the ideological level, it can be concluded that freedom of lifestyle, sensuality, anti-establishment is the right of every individual and they have the right to do whatever they want

Keywords: Film studies; film semiotics; television studies; television semiotics; video clip

Korespondensi: Winda Yunita Lestari. Universitas Telkom. Jl.Telekomunikasi No.01, Terusan Buah Batu, Sukapura, Dayeuhkolot, Bandung, Jawa Barat 40257.Email: windayunitaaa@yahoo.com 


\section{PENDAHULUAN}

Illuminati merupakan kelompok elit yang memiliki pertalian darah. Tujuan utama dari ordo Illuminati adalah mewujudkan masyarakat dengan tatanan dunia baru, yaitu mengalihkan manusia dari jalan Tuhan dan menaklukan mereka dengan cara-cara yang canggih untuk mengendalikan pikiran (yaitu media massa, pendidikan, kebebasan seksual, migrasi, keberagaman, dan lain-lain) (Makow, 2012). Kelompok ini memiliki strategi untuk menguasai dunia. Salah satu strateginya adalah penghancuran agama-agama besar diseluruh dunia, peruntuhan monarki dan pemerintahan yang teratur, penghilangan kepemilikan pribadi (yang akan diambil oleh Illuminati), penghilangan patriotisme bangsa, penghapusan dan penguasaan terhadap ikatan keluarga (Makow, 2012). Strategi tersebut didukung oleh kelompok pendukung Illuminati, yaitu Kabbalah. Kabbalah sendiri adalah orang-orang yang memuja setan, menguasai ilmu-ilmu supranatural, berencana menaklukkan dunia di bawah satu kepemimpinan. Kabbalah tidak pernah menjadi tokoh "di depan panggung", mereka membentuk kelompok-kelompok tersembunyi dan tidak terlacak seperti Illuminati. Namun, dibalik itu semua kabbalah adalah kelompok yang lebih tersembunyi, mereka adalah “dalang” dari kelompok
Illuminati (Ezza, 2014).

Simbol Illuminati digunakan untuk mempertahankan eksistensi mereka. Ritual, upacara, gerakan tangan dan genggaman tangan Iluminis dilandaskan oleh sains dan simbolisme. Mereka mempercayai kekuatan gaib(okultisme). Okultisme sendiri adalah kepercayaan terhadap kekuatan gaib yang dapat dikuasai oleh manusia (Makow, 2012). Menurut Alex Horne, lambang adalah sesuatu yang merepresentasikan sesuatu yang lain, sedangkan simbol memiliki makna moral dan spiritual (Marrs, 2013).

Simbol saat ini telah menyebar melalui media massa, diantaranya melaui media film, iklan maupun video klip. Simbol Illuminati disebarkan melalui media massa, mereka mengontrol dengan cara mengendalikan apa yang kita dengar dan apa yang kita lihat. Simbol-simbol milik organisasi ini yang cukup familiar di antaranya adalah segitiga yang di atasnya terdapat satu mata, lalu gambar bintang yang terbalik, terlihat membentuk sebuah kepala kambing yang disebut dengan Lucifer, kemudian ada juga simbol All Seeing Eye, Pentagram, Bintang David, Dewa Ra, dan lainlainya.

Ada beberapa penyanyi atau grup band yang memasukkan simbol-simbol Illuminati dalam video klip-nya. Penyanyi berkebangsaan Amerika Serikat bernama Kesha Rose Sebert atau dikenal dengan nama panggung Ke\$ha, 
Tabel 1 Data Video Klip yang menampilkan Simbol Illuminati Versi Collective Evolution

\begin{tabular}{ccc}
\hline No & Penyanyi & Judul Lagu \\
\hline 1 & Britney Spears & Hold It Againts Me \\
\hline 2 & Eminem Ft. Rihanna & The Monster \\
\hline 3 & Lady Gaga & Bad Romance \\
\hline 4 & Lady Gaga & Judas \\
\hline 5 & Lil Wayne Ft. Drake, & Love Me \\
\hline 6 & Future & Umbrella \\
\hline 7 & Rihana & Scream \\
& Will .I. Am Ft. & Shout \\
\hline 8 & Britney & Dark Horse \\
\hline 9 & Katy Parry & Alejandro \\
\hline 10 & Lady Gaga & Die Young \\
\hline
\end{tabular}

Sumber: observasi peneliti, 2018

sengaja memasukkan simbol-simbol Illuminati di dalam video klip-nya yang berjudul Die Young. Video klip ini mendapat perhatian lebih dari 138 ribu viewers dan 3,4 juta subscribe di seluruh dunia. Video klip berdurasi kurang dari 4 menit ini menceritakan tentang penggerebekan terhadap sebuah Gereja, karena mereka menggunakan Gereja tersebut untuk melakukan pemujaan terhadap seks dan diakhiri dengan datangnya polisi untuk mengamankan gereja. Menjadi menarik karena dalam video klip ini terdapat simbol-simbol Illuminati yang digunakan sebagai transisi serta setting dalam pengambilan gambarnya.

Berdasarkan web Collective Evolution menyatakan bahwa terdapat 10 video klip yang mengandung unsur simbol Illuminati. Die Young menjadi video klip dengan jumlah simbol dan pengulangan paling banyak bila dibandingkan dengan 9 video klip yang lainnya. Hal ini menjadi menarik untuk dijadikan sebagai objek penelitian.

Dalam penelitian kualitatif ini, peneliti menggunakan metode semiotika John Fiske untuk mengungkap pemaknaan dari simbolsimbol iluminati yang ada di video klip Die Young. Simbol-simbol iluminati akan dimaknai

Tabel 2 Data Video Klip dengan Unsur Simbol Illuminati

\begin{tabular}{|c|c|c|c|c|c|}
\hline No & Penyanyi & Judul Lagu & Tahun Rilis & $\begin{array}{l}\text { S i m b o l } \\
\text { Iluminati Yang } \\
\text { Muncul }\end{array}$ & 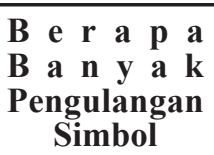 \\
\hline 1 & Britney Spears & Hold It Againts Me & 2011 & 1 & 1 kali \\
\hline 2 & Eminem Ft. Rihanna & The Monster & 2013 & 1 & 2 kali \\
\hline 3 & Lady Gaga & Bad Romance & 2009 & 3 & 4 kali \\
\hline 4 & Lady Gaga & Judas & 2011 & 2 & 6 kali \\
\hline 5 & $\begin{array}{c}\text { Lil Wayne Ft. Drake, } \\
\text { Future }\end{array}$ & Love Me & 2013 & 2 & 2 kali \\
\hline 6 & Rihana & Umbrella & 2007 & 2 & 7 kali \\
\hline 7 & $\begin{array}{l}\text { Will I. Am Ft. } \\
\text { Britney }\end{array}$ & Scream \& Shout & 2012 & 5 & 9 kali \\
\hline 8 & Katy Parry & Dark Horse & 2013 & 3 & 20 kali \\
\hline 9 & Lady Gaga & Alejandro & 2010 & 4 & 13 kali \\
\hline 10 & KeSha & Die Young & 2012 & 5 & 41 kali \\
\hline
\end{tabular}


dalam tiga level, yaitu level realitas, level representasi dan level ideologi. Analisis melalui tiga level ini berfungsi untuk memaparkan bagaimana simbol-simbol tersebut dikonstruksi sebagai realitasdalam bentuk video klip oleh pembuatnya, kemudian bagaimana realitas tersebut direpresentasikan dalam video klip dan bagaimana kode-kode representasi tersebut dihubungkan dengan konteks sosial sehingga menghasilkan konvensi-konvensi yang dapat diterima secara ideologis.

\section{TINJAUAN PUSTAKA}

Video klip mempunyai unsur suara dan gambar. Pada umumnya video klip dibuat untuk mempromosikan lagu dari sebuah grup musik atau seorang musisi. Video klip juga seringkali digunakan untuk mempromosikan sebuah film. Video klip dapat dikatakan sebagai sebuah film berdasarkan lagu, kombinasi dari lagu seorang musisi atau grup, dengan kekuatan visual. Gaya dalam video klip musik dapat mencerminkan suasana tema dari lagu, mem-visualisasikan isi syair lagu melalui beberapa gaya. Secara umum definisi video klip adalah kumpulan potonganpotongan visual yang dirangkai dengan atau tanpa efek-efek tertentu dan disesuaikan berdasarkan ketukan-ketukan pada irama lagu, nada, lirik, instrumennya untuk mengenalkan dan memasarkan lagu agar masyarakat dapat mengenalnya.
Pengambilan gambar adalah tahapan terpenting di dalam proses produksi. Menurut Semedhi, ada beberapa hal yang harus diperhatikan terkait dengan teknik pengambilan gambar (Semedhi, 2011). Pertama adalah Komposisi, yaitu suatu cara untuk meletakkan objek gambar di dalam layar sehingga gambar tampak menarik, menonjol dan bisa mendukung alur cerita. Kedua adalah Intersection of third (Rule of Third), yaitu bidangyang kita lihat secara binocular (melihat sesuatu maka pandangan kita terarah secara sejajar) tersebut dijadikan titik pusat perhatian atau points of interest suatu gambar. Ketiga adalah Golden Main Area yaitu cara untuk membuat komposisi gambar yang baik, khususnya untuk pengambilan gambar dengan ukuran medium close up atau close up. Keempat adalah Diagonal Depth yang menjelaskan tentang pengambilan gambar secara long shot. Pengambilan gambar ini harus mempertimbangkan unsur-unsur diagonal sebagai komponen gambarnya. Unsur diagonal penting artinya untuk memberikan kesan "depth" atau kedalaman. Unsur diagonal akan memberikan kesan tiga dimensi.

Menurut Roy Thompson, ukuran shot terdiri atas Extreme Long Shot (ELS), Very Long Shot (VLS), Long Shot (LS), Medium Long Shot (MLS), Medium Shot (MS), Medium Clos Up (MCU), Close Up (CU), Big Close Up (BCU) serta Extreme Clos Up (ECU) (Naratama, 2004). 
Gabungan yang baik dari ukuran shot ini, akan membangun sebuah bahasa visual yang baik, sehingga pesan dapat tersampaikan melalui bahasa visual.

Lighting adalah komponen utama dan mempunyai peran yang sangat penting di dalam produksi sebuah film atau video.Dengan pengaturan lighting yang tepat, kita bisa memberi efek positif atau negatif terhadap objek yang kita shot. Bahkan dengan pencahayaan tertentu, kita bisa membuat efek sedih, gembira, takut, berani, suram, cerah dan lain sebagainya (Semedhi, 2011).

Pencahayaan pada dasarnya terbagi dalam tiga jenis, yaitu (1). Key Light, yaitu pencahayaan utama dalam penyinaran objek. (2). Fill Light, yaitu pencahayaan yang bertujuan untuk mengurangi bayangan yang dihasilkan Key Light.(3). Back Light, yaitu pencahayaan yang bertujuan untuk memisahkan antara objek dengan background.

Editing pada tahap produksi adalah proses pemilihan serta penyambungan gambar-gambar yang telah diambil. Dalam sebuah editing, diperlukan transisi shot, dengan beberapa istilah, yaitu cut, fade-in/out, dissolve, serta wipe. Cut dapat digunakan untuk editing kontinu dan diskontinu. Sementara wipe, dissolve dan fade umumnya digunakan untuk editing diskontinu.

Illuminati yang berarti "yang tersinari" dan mengacu pada Lucifer "pembawa cahaya", didirikan pada tanggal 1 Mei 1776 oleh Adam Weishaupt yang bertujuan untuk merendahkan dan memperbudak manusia 'tanpa disadari oleh manusia itu sendiri', baik secara mental maupun spiritual. Illuminati mengendalikan pembangunan di sebagian besar dunia saat ini, terutama di Eropa dan Amerika. Mereka menjadi sebuah kelompok yang eksklusif, penggerak dan pengendali dunia dan ternyata mereka memiliki pertalian darah dan biasa disebut sebagai "para Satanis generasional". Mereka menerapkan ajaran ini dari generasi ke generasi berikutnya. Tujuan utama mereka adalah untuk mewujudkan apa yang disebut oleh masyarakat sebagai Tatanan Dunia Baru yang menarik perhatian dunia dan menyandang gelar "The Antichrist" (Makow, 2012).

Makow menyatakan bahwa pada dasarnya, setiap negara dijalankan oleh pemerintah bayangan yang memiliki loyalitas terhadap Tatanan Dunia Baru yang dikendalikan oleh 13 anggota Illuminati Council. Illuminati juga menggunakan uang suap dan seks untuk dapat mengendalikan orang-orang kelas atas dan kemudian memeras mereka dengan ancaman kehancuran finansial, penyebaran berita buruk mereka kepada publik atau pembunuhan, hal ini tetap berlanjut hingga saat ini (Makow, 2012). Tatanan Dunia Baru adalah upaya untuk menyingkirkan Tuhan dan menggantikannya dengan setan. Ia mengatakan bahwa hitam 
adalah putih, kejahatan adalah kebaikan. Ia menciptakan realitas semu yang didesain untuk melayani beberapa pihak dan memperbudak banyak pihak (Makow, 2012).

Ada banyak macam-macam simbol Illuminati yang digunakan dalam perkumpulan Illuminati. Namun, terdapat beberapa simbol yang sering muncul dalam kehidupan seharihari yang dapat kita kenal sebagai simbol Illuminati.

Untuk mempertahankan perkumpulan rahasia mereka, para pemimpin dan kelompok Illuminati menggunakan simbol. Ritual, upacara, gerakan tangan dan genggaman tangan Illuminis dilandaskan pada sains dan simbolisme.

Bagi kelompok Illuminis lainnya, simbol okultisme (kepercayaan terhadap hal-hal mistis) mereka juga mengandung serangkaian makna beragam dan mendalam. Alex Horne, dalam Sources of Masonic Symbolism, membedakan antara 'lambang' dan 'simbol'. Menurutnya, lambang adalah sesuatu yang merepresentasikan sesuatu yang lain, sedangkan simbol memiliki makna moral dan spiritual.

Makna moral dan spiritual itu terpaksa dirahasiakan oleh anggota ini. Sekalipun dirahasiakan, simbol dan lambang Illuminati memiliki energy kuat (Marrs, 2013).

Berikut beberapa contoh simbol Illuminati yang sering digunakan oleh ordo Illuminati:
Kalangan Iluminis dan penyihir mengklaim bahwa pentagram, bintang berujung lima dengan satu ujung ke atas berguna bagi ritual dan mantra 'Sihir Putih'. Pentagram (bintang berujung lima) terbalik banyak digunakan oleh penyembah setan garis keras. Ketika dua ujung diarahkan ke atas, kabarnya untuk mengindikasikan 'Sihir Hitam' dan bermakna dua tanduk setan (Marrs, 2013). Pentagram dengan dua tanduk yang menunjuk ke atas merepresentasikan Setan, atau Kambing Sabbath. (Tanduk) mengarah ke bawah tentunya mewakili ruh jahat, yaitu subversi intelektual, kekacauan, dan kebodohan.

Pentagram dengan satu titik di atas adalah sebuah simbol standar untuk penyihir, Freemason, dan banyak kelompok gaib lainnya. Untuk penyihir, itu mewakili empat elemen dasar (angin, air, tanah dan api) ditambah panteistik spiritual seperti Gaia atau Ibu Pertiwi. Pentagram juga digunakan untuk perlindungan (http://www.crossroad.to/Books/symbols1. html, 2015). Sedangkan pentagram dengan dua titik di atas digunakan dalam ritual okultisme untuk mengarahkan kekuatan atau energi. Sering mewakili satanisme, dewa bertanduk atau berbagai ekspresi okultisme kontemporer, terutama ketika kambing-kepala ditumpangkan pada pentagram terbalik dalam "suci” lingkaran.

The All Seeing Eye atau Eye Providence adalah simbol utama ordo Illuminati sekaligus 


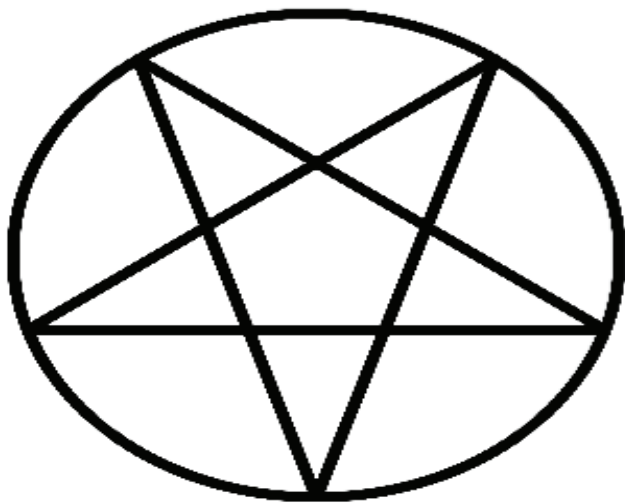

Sumber: http://www.crossroad.to/Books/symbols1.html. 2018

\section{Gambar 1 Pentagram One Point Upward}

menjadi simbol mereka yang paling banyak digunakan dan terkenal luas di hati masyarakat dunia. Simbol tersebut berupa mata satu. Simbol ini memiliki arti bahwa mata tersebut adalah mata Lucifer. Lucifer sendiri adalah iblis yang terkutuk dalam Injil. Dalam Illuminati, Lucifer diyakini sebagai saudara Yesus Kristus. Gagasan yang tersimpan dalam Mata-Satu adalah bahwa mata tersebut dapat melihat semua hal dan mengawasi para pelayannya (Ezza, 2014). Barbara Walker menguraikan bagaimana kepercayaan misteri kuno sangat menghormati segitiga sebagai simbol dewa. Ia mencatat bahwa penganut Hindu juga meminjamnya sebagai Segitiga Kehidupan wanita (seksual) tantra mereka. Di Mesir, segitiga adalah simbol hieroglif bagi 'wanita'. Di Yunani kuno, maksud seksual tampak jelas dalam segitiga itu yang mewakili Pintu Suci, genitalia Dementer Bunda, yang dikenal sebagai 'Bunda Delta' (Walker, 1995).

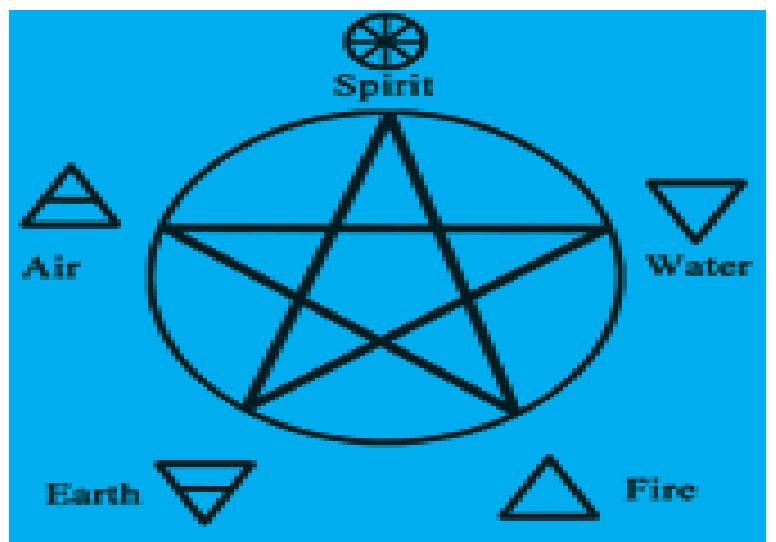

Sumber: http://www.crossroad.to/Books/symbols1.html, 2018

Gambar 2 Pentagram Two Point Upward

Bagi kelompok okultis, segitiga menunjuk ke atas mewakili api dan menunjuk ke bawah mewakili air. Menggabungkan, menyeimbangkan dan menyatukan dua unsur itu akan meengahasilkan dualism, atau ekuilibrium, yang merupakan tujuan Freemansori dan ajaran utama seluruh system keagamaan Iluminis (Marrs, 2013).

Salah satu simbol setan yang paling populer adalah terbalik salib, alasan di balik yang tampaknya cukup jelas. Dengan kemungkinan

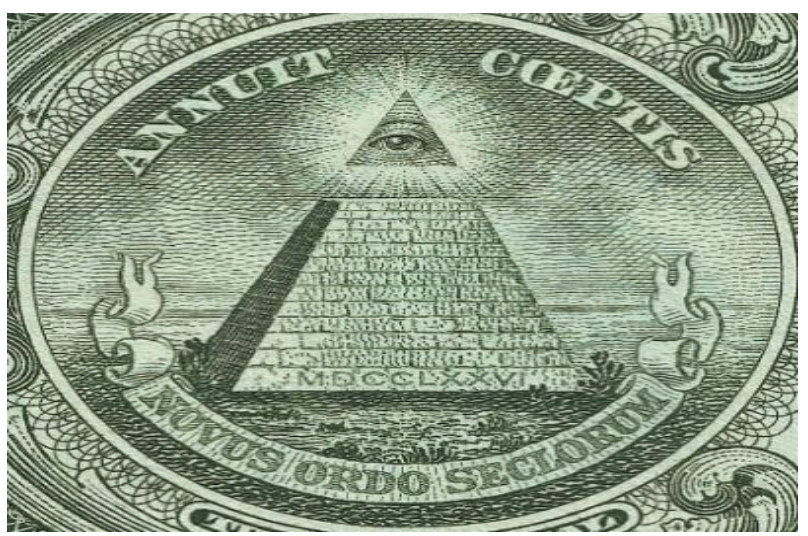

Sumber: http://www.crossroad.to/Books/symbols1.html, 2018

Gambar 3 Simbol All Seeing Eye 


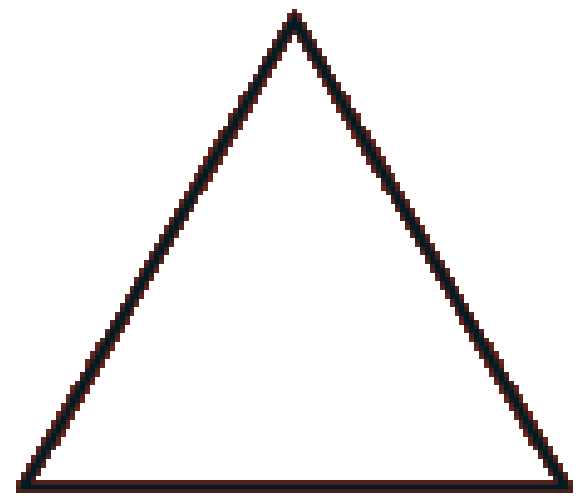

Sumber: http://www.crossroad.to/Books/symbols1.html, 2018

\section{Gambar 4 Simbol Triangle}

pengecualian benda pentagram dengan kepala kambing di dalamnya. Salib terbalik adalah simbol yang paling segera dikenali dari pembangkangan terhadap kekristenan (Moon, 2010).

Semiotika adalah suatu ilmu atau metode analisis untuk mengkaji tanda. Tanda-tanda adalah perangkat yang kita pakai dalam manusia dan bersama-sama manusia. Semiotika, atau dalam istilah Barthes, semiologi, pada dasarnya hendak mempelajari bagaimana kemanusiaan (humanity) memaknai hal-hal (things). Memaknai (to signify) dalam hal ini tidak dapat dicampuradukkan dengan mengkomunikasikan (to communicate). Memaknai berarti bahwa objek-objek tidak hanya membawa informasi, dalam hal mana objek-objek itu hendak berkomunikasi, tetapi juga mengkonstitusi sistem terstruktur dari tanda (Sobur, 2013).

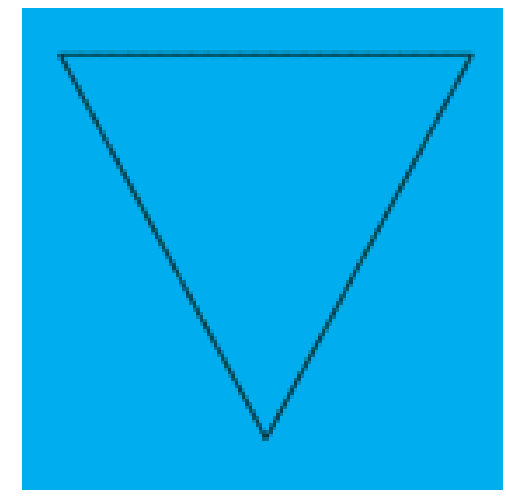

Sumber: http://www.crossroad.to/Books/symbols1.html, 2018

\section{Gambar 5 Simbol Inverted Triangle}

Tradisi semiotika mencakup teori utama mengenai bagaimana tanda mewaliki objek, ide, situasi, keadaan, perasaan, dan sebagainya yang berada diluar diri. Studi mengenai tanda tidak saja memberikan jalan atau cara dalam mempelajari komunikasi tetapi juga memiliki efek besar pada hampir setiap aspek (perspektif) yang digunakan dalam teori komunikasi (Morissan, 2013).

Menurut Culler, semiotika adalah instrument pembuka rahasia teks dan penandaan, karena semiotika adalah puncak logis dari apa yang disebut Derida sebagai "logosentrisme". Budaya barat: rasionalitas yang memperlakukan makna sebagai konsep atau representasi logis yang merupakan fungsi tanda sebagai ekspresi (Vera, 2014).

Istilah makna memang merupakan istilah yang membingunkan. Maka itu, batasannya 


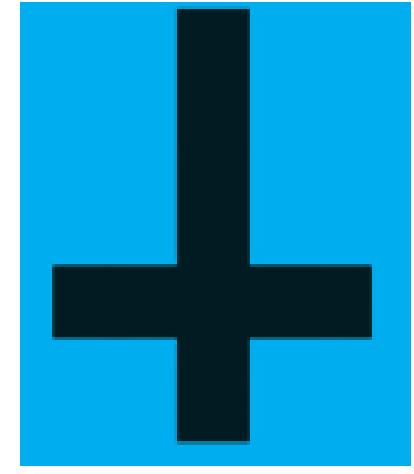

Sumber: http://www.crossroad.to/Books/symbols1.html, 2018

\section{Gambar 6 Simbol The Inverted Cross}

pun bisa bermacam-macam (Sobur, 2013). Menurut Aubrey Fisher, definisi langsung tentang konsep makna bukanlah permasalahan. "Kita, dibiarkan dengan penafsiran makna yang berbeda, seringkali dalam bentuk aturan kaitan (correspondence rules) atau definisi operasional, dan tidak mencapai consensus yang jelas tentang hakikat konsep makna tersebut" (Sobur, 2013).

Menurut Hall, “..representation is an essential part of the process by which meaning is produced and exchanged between members of the culture," (Hall, 1997). Melalui representasi, suatu makna diproduksi dan dipertukarkan anggota masyarakat. Dapat dikatakan bahwa representasi adalah salah satu cara untuk memproduksi makna.

Representasi bekerja melalui sistem representasi. Sistem representasi ini terdiri dari dua komponen penting, yakni konsep dalam pikiran dan bahasa. Kedua komponen ini saling berelasi. Konsep dari sesuatu hal yang kita miliki dalam pikiran kita, membuat kita mengetahui makna dari hal tersebut. Namun, makna tidak akan dapat dikomunikasikan tanpa bahasa. Representasi merupakan aplikasi atau penggambaran makna yag abstrak menjadi tindakan yang riil (Rosfiantika, Mahameruaji, \& Permana, 2017).

Pemaknaan terhadap sesuatu dapat sangat berbeda salam budaya atau kelompok masyarakat yang berlainan karena pada masingmasing budaya atau kelompok masyrakat tersebut ada cara-cara tersendiri dalam memaknai sesuatu. Kelompok masyarakat yang memiliki latar belakang pemahaman yang tidak sama diproduksi oleh kelompok masyarakat lain.

Makna tidak lain adalah suatu konstruksi. Manusia mengkonstruksi makna dengan sangat tegas sehingga suatu makna terlihat melalui sistem representasi dan difiksasi melalui kode. Kode inilah yang membuat masyarakat yang berada dalam suatu kelompok budaya yang sama mengerti dan menggunakan nama yang sama, yang telah melewati proses konvensi secara sosial. Kode, membangun korelasi antara sistem konseptual yang ada dalam pikiran kita dengan sistem bahasa yang kita gunakan.

Makna bisa beragam, tentunya untuk meningkatkan fungsi edukatif dan fungsi 
informatif bagi para penontonnya (Indriani \& Prasanti, 2017). Dapat disimpulkan bahwa representasi adalah suatu proses untuk memproduksi makna dari konsep yang ada dipikiran kita melalui bahasa.

John Fiske mengemukakan teori tentang kode-kode televisi (the codes of television). Menurut Fiske, kode-kode yang muncul atau yang digunakan dalam acara televisi saling berhubungan sehingga terbentuk sebuah makna. Menurut teori ini pula, sebuah realitas tidak muncul begitu saja melalui kode-kode yang timbul, namun juga diolah melalui penginderaan sesuai referensi yang telah dimiliki oleh pemirsa televisi, sehingga sebuah kode akan dipersepsi secara berbeda oleh orang yang berbeda juga. Pada perkembangannya, model dari John Fiske tidak hanya digunakan dalam menganalisis acara televisi, tetapi dapat juga digunakan untuk menganalisis teks media yang lain, seperti film, iklan dan lain-lain (Vera, 2014).

Dalam kode-kode televisi yang diungkapkan dalam teori John Fiske, bahwa peristiwa yang ditayangkan dalam dunia televisi telah dikodekan oleh kode- kode sosial yang terbagi dalam tiga level berikut (Vera, 2014):

Pada level pertama, peristiwa yang ditandakan(encode) sebagai realitas. Bagaimana peristiwa itu dikonstruksi sebagai realitas oleh wartawan/media. Dalam bahasa gambar (terutama televisi) ini umumnya berhubungan dengan aspek seperti pakaian, lingkungan, ucapan dan ekspresi. Di sini, realitas selalu siap ditandakan, ketika kita menganggap dan mengkonstruksi peristiwa tersebut sebagai sebuah realitas.

Pada level kedua, ketika kita memandang sesuatu sebagai realitas itu digambarkan. Di sini, kita menggunakan perangkat secara teknis. Dalam bahasa tulis, alat teknis itu adalah kata, kalimat atau proposisi, grafik dan sebagainya. Dalam bahasa gambar/televise, alat itu berupa kamera, pencahayaan, editing atau music. Pemakaian kata-kata, kalimat, atau proposisi tertentu, misalnya, membawa makna tertentu ketika diterima oleh khalayak.

Pada level ketiga, organisasi pemaknaan terhadap peristiwa-peristiwa ke dalam konvensi-konvensi yang diterima secara ideologis. Bagaimana kode-kode representasi dihubungkan dan diorganisasikan ke dalam koherensi sosial seperti kelas sosial, atau kepercayaan dominan yang ada di dalam masyarakat (patriarki, materialism, kapitalisme dan sebagainya)

\section{METODE PENELITIAN}

Penelitian ini akan menganalisis tentang bagaimana membongkar Makna Simbol Illuminati direpresentasikan dalam Video Klip "Die Young” berdasarkan atas simbolsimbol yang muncul dalam teks video klip 
tersebut. Penelitian Kualitatif ini menggunakan pendekatan semiotika dari John Fiske sebagai metode penelitiannya.

Penelitian ini menggunakan Unit analisis berupa visualisasi simbol-simbol Illuminati yang terdapat dalam video klip Die Young. Terdapat 6 visualisasi yang menampilkan simbol Illuminati. Keenam simbol ini akan dibedah dengan menggunakan metode semiotika John Fiske.

Penelitian ini menggunakan data primer dan sekunder. Data primer dalam penelitian ini adalah video klip Ke\$ha yang berjudul "Die Young" yang telah dipilih dalam bentuk adegan-adegan (scene) yang menampilkan symbol Illuminati. Untuk data sekunder, peneliti menggunakan studi literatur dengan cara membaca, mempelajari dan menganalisis dokumen dan sumber data melalui buku-buku, penelitian terdahulu, internet serta sumber data yang lain seperti skripsi guna mendukung hasil penelitian.

\section{HASIL DAN PEMBAHASAN}

Video klip Die Young yang dipopulerkan oleh Ke\$ha, dibuat pada tahun 2012 oleh perusahaan rekaman RCA Records, anak perusahaan dari Sony Music Entertaintment. Video klip ini menceritakan seorang pemimpin perempuan yang datang ke sebuah Gereja bersama para pengikutnya untuk melakukan aktivitas pemujaan di dalam Gereja tersebut. Mereka melakukan berbagai kegiatan seksual didalam Gereja tersebut seperti bercumbu dengan menampilkan berbagai macam simbolsimbol yang diduga simbol yang dipakai oleh kelompok Illuminati, seperti pentagram, salib terbalik, segitiga terbalik, All Seeing Eye, peace sebagai objek dan juga transisi yang dipakai dalam video klip tersebut. Pada akhir adegan (scene), para polisi mengepung Gereja tersebut dan pemimpin perempuan tersebut menyerahkan diri kepada polisi.

Bagi sebagian orang awam yang tidak mengetahui simbol-simbol Illuminati, akan beranggapan bahwa simbol tersebut hanyalah simbol biasa. Ini adalah bagian dari misi Illuminati yang berusaha untuk menyebarkan simbol-simbol tersebut agar masyarakat terbiasa dengan simbol-simbol Illuminati tersebut, sehingga akhirnya masyarakatpun menggunakan simbol mereka secara sadar atau tidak sadar dalam kehidupan sehari-hari.

Ke\$ha sebagai penyanyi lagu Die Young sengaja memasukkan simbol-simbol tersebut ke dalam video klipnya. Ke\$ha mencoba untuk mensosialisasikan kepada publik agar publik dapat melihat, bahkan mungkin menikmati sajian visualisasi simbol-simbol Illuminati yang dipakai dalam video klip tersebut. Simbolsimbol Illuminati yang digunakan dalam video klip ini ditampilkan dengan sangat eye catching 
sehingga siapapun yang menonton, simbol Illuminati ini menjadi point of interest.

Dalam penelitian ini, enam unit analisis akan dianalisa menggunakan semiotika John Fiske. Enam unit analisis ini dipilih berdasarkan pada fokus penelitian, yaitu adegan (scene) yang menampilkan simbol Illuminati. Penelitian ini menggunakan analisis semiotika kode-kode televisi John Fiske. Pada level realitas tandatanda yang akan dianalisis berupa ekspresi dan gesture. Pada level representasi, tanda-tanda yang akan dianalisis berupa teknik pengambilan gambar, pencahayaan dan editing. Dari elemen yang terbentuk melalui level realitas dan representasi, maka akan terbentuk ideologi yang terdapat dalam video klip Die Young.

Scene ini menunjukkan Ke\$ha sedang menatap tajam ke arah kamera (menatap penonton) dengan memperlihatkan cincin berbentuk oval dengan bulatan di tengah yang menyerupai sebuah mata. Dalam Illuminati, cincin tersebut dikenal dengan simbol All

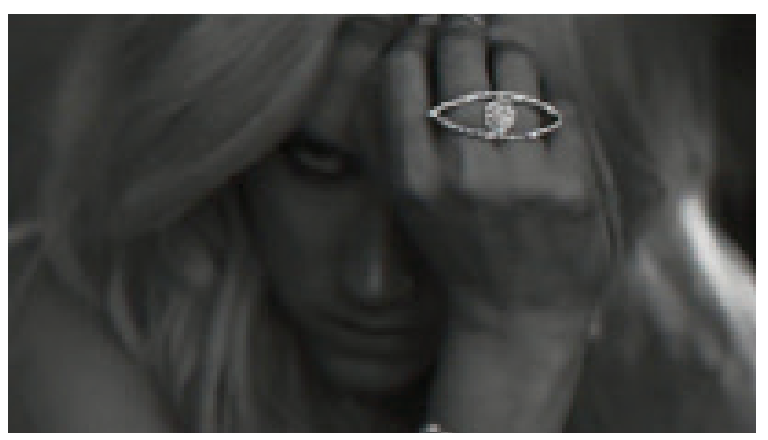

Sumber: Tangkapan Layar Dari Youtube, 2018

Gambar 7 Simbol All Seeing Eye dalam bentuk cincin
Seeing Eye.

Pada level realitas yang diperlihatkan melalui ekspresi adalah keseriusan yang diperlihatkan oleh Ke\$ha pada saat memperlihatkan cincinnya yang berbentuk mata yang menyerupai simbol All Seeing Eye. Simbol Illuminati diperlihatkan dengan penuh keseriusan di dalam scene pertama. Kesan yang ditimbulkan oleh Ke\$ha melalui ekspresinya memperlihatkan bahwa Ke\$ha ingin melakukan kontak lebih intim kepada para penonton atau fansnya, sehingga dari hal tersebut menandakan bahwa Ke\$ha mencoba untuk 'menantang' para penonton atau fansnya dengan tatapan tajamnya. Dalam hal ini, Ke\$ha mencoba untuk mengajak penonton atau fansnya untuk memperlihatkan apa yang ia kenakan dalam scene tersebut. Dominasi komposisi pada cincin bertujuan untuk memperkenalkan simbol Illuminati, yaitu simbol All Seeing Eye kepada para fansnya.

Tanda kedua dalam level realitas adalah gesture tangan kanan yang berada di depan wajahnya untuk menunjukkan eksistensi cincin tersebut. Ia ingin memperlihatkan lebih jelas dengan menggunakan tangannya sebagai perantara untuk menunjukkan simbol Illuminati yang berada di jarinya.

Jika dikaitkan dengan teknik pengambilan gambar secara close up, sutradara ingin menonjolkan sisi dominasi atas cincin yang berbentuk simbol All Seeing Eye tersebut. Selain 
itu, sutradara juga menciptakan kedekatan agar para penonton dapat melihat ekspresi Ke\$ha. Ke\$ha terlihat sedikit menundukkan kepala agar cincin yang ia kenakan terlihat mendominasi di atas kepala Ke\$ha.

Pencahayaan yang digunakan di dalam scene ini dibuat minimalis, terlihat bahwa scene tersebut dominan dengan warna hitam. Dalam hal ini, cahaya dalam scene tersebut memperlihatkan Ke\$ha dengan suasana yang cukup mencekam karena warna dari cahaya yang ditimbulkan tidak terlalu banyak sehingga membuat warna disekitar latar Ke\$ha menjadi gelap.

Merujuk pada psikologi warna, hitam dapat menggambarkan sebuah kekuatan, keseriusan, kemewahan dan kesempurnaan (Dameria, 2007). Sedangkan cincin yang diindikasikan sebagai simbol All Seeing Eye yang digunakan oleh Ke\$ha berwarna putih. Warna putih sendiri dapat menggambarkan kemurnian, kejujuran dan ketidak berdosaan. Simbol All Seeing Eye berhubungan dengan sebuah misteri, kegelapan dan adanya sebuah kekuatan di dalamnya.

Editing yang digunakan di dalam scene ini juga menggunakan teknik dramatic tension yang berhubungan dengan pembentukan rasa (mood) serta untuk menarik perhatian seseorang. Scene ini muncul setelah scene Ke\$ha dan para pengikutnya memasuki gereja. Scene ini tidak menggunakan ritme yang menyesuaikan dengan ketukan atau irama lagu, sehingga ia memang dimunculkan selama 5 detik saja untuk memperlihatkan simbol All Seeing Eye yang ada pada jari Ke\$ha. Setelah scene ini dimunculkan, lalu muncul scene yang mengikuti ritme atau ketukan dari lagu.

Dalam hal ini, Ke\$ha mencoba untuk mensosialisasikan setiap simbol okultisme tersebut kepada para penonton atau fansnya. Gesture jari yang mengapit matanya tersebut menandakan bahwa ia memfokuskan pandangan kepada para penonton agar mereka melihat dengan seksama simbol yang ada di dalam scene tersebut.

Cara pengambilan secara extreme close up dirasa sangat cocok untuk menonjolkan detail bagian tubuh seseorang dalam hal ini mata untuk disejajarkan dengan simbol All Seeing Eye yang berada tepat di depan matanya. Dalam hal ini diperlihatkan bagian mata dari Ke\$ha. Mata dan simbol All Seeing Eye yang ditunjukkan dalam scene ini memberikan dominasi yang kuat untuk diperlihatkan kepada para khalayak. Setidaknya ada empat kali simbol tersebut berkelap-kelip dalam scene ini. Mata Ke\$ha tersebut ingin menyamakan kedudukan dengan simbol All Seeing Eye yang notabennya simbol tersebut menerangkan tentang mata dewa Horus.

Pencahayaan yang digunakan dalam scene ini juga menggunakan pencahayaan soft light atau cahaya yang lunak. Cahaya ini berfungsi 
agar gambar terlihat lebih halus di depan kamera, karena pengambilan gambar yang benar- benar dekat dengan objek yang disoroti. Cahaya yang lunak digunakan agar mata yang diperlihatkan Ke\$ha dapat terlihat dengan baik tanpa adanya kelebihan cahaya. Simbol All Seeing Eye dalam scene tersebut juga memperlihatkan warna cerah. Warna tersebut terlihat seperti warna merah muda. Warna merah muda sekali lagi melambangkan jiwa muda, ceria, sensualitas.

Teknik editing yang digunakan menggunakan teknik dramatic tension yang menekankan pada pemusatan perhatian para penonton. Pemusatan perhatian ini diperlihatkan pada saat simbol yang berwarna merah muda tersebut berkelap- kelip sebanyak 4 kali secara cepat, sehingga hal ini akan menjadi daya tarik para penonton untuk melihat simbol tersebut. Selain itu, scene pemunculkan simbol ini muncul pada saat para polisi sudah mengepung Gereja yang dipakai oleh Ke\$ha untuk melaksanakan ritualnya. Scene ini muncul untuk memberikan perhatian kepada para penonton.

Dengan menggunakan teknik pengambilan gambar full shot, adeganini memperlihatkan suasana setting atau latar yang berada di hadapan Ke\$ha. Pengambilan gambar secara full shot juga berfungsi untuk memperlihatkan adanya simbol All Seeing Eye yang terletak di belakang badan Ke\$ha. Dengan begitu, ketika Ke\$ha berjalan keluar dari Gereja tersebut, perhatian penonton akan mengarah kepada simbol yang berada di belakang Ke\$ha. Ke\$ha mencoba untuk menyembunyikan identitas dari simbol tersebut agar polisi tidak mengetahui adanya keterlibatan simbol di dalam Gereja tersebut.

Pencahayaan yang digunakan di dalam scene ini menggunakan cahaya yang tajam yang berasal dari lampu luar ruangan dan lampu mobil yang menyoroti Ke\$ha pada saat ia mengangkat tangan. Hal ini berfungsi untuk memperlihatkan detail aksi yang sedang dilakukan oleh Ke\$ha di depan pintu Gereja.

Teknik editing yang digunakan menggunakan dramatic tension untuk membangun rasa (mood) dan menarik perhatian para penonton. Teknik editing ini dilakukan untuk melihat aksi apakah yang akan dilakukan oleh Ke\$ha pada scene terakhir ini dan apa yang ia bawa pada saat keluar dari Gereja tersebut. Ternyata Ke\$ha mencoba untuk menyerahkan diri kepada polisi dan menyembunyikan kehadiran simbol tersebut dibalakang tubuhnya. Penempatan scene ini dibuat secara paralel yang diselipkan oleh scene-scene pendukung lainnya untuk mendukung jalan cerita utama. Scene ini tidak mengikuti ritme pada lagu, tapi ia mencoba untuk membagi jalan cerita menjadi 3 bagian dimana scene tersebut disisipi oleh scene lain sebagai scene pendukung.

Keberadaan simbol All Seeing Eye dalam video klipini terlihat selalu di ekspose dengan 
cara memunculkan simbol-simbol tersebut secara lebih dominan. Keberadaan simbol yang berada di belakang pinggang.

Scene ini memperlihatkan simbol segitiga terbalik sebagai point of interest dengan corak berwarna merah muda. Dibelakang simbol tersebut terdapat background bling-bling seperti berlian. Terlihat suasana gelap dan mencekam di dalam scene ini.

Pernikahan seharusnya dilakukan oleh sepasang manusia yang memiliki perbedaan jenis kelamin agar mereka dapat menghasilkan keturunan. Namun, dengan adanya pembebasan hak kaum gay, maka sistem keluarga dalam suatu masyarakat akan hancur. Karena pernikahan sesama jenis tidak akan bisa mendapatkan keturunan. Dalam hal ini, Ke\$ha mendukung adanya pembebasan hak kaum gay.

Background scene ini memperlihatkan bentuk pecahan kristal. Tampilan ini untuk memberikan kesan bahwa Illuminati adalah ajaran yang berkelas. Simbol segitiga terbalik diartikan sebagai segitiga yang diyakini oleh kelompok Illuminati sebagai simbol dari pembebasan hak kaum gay dan mereka menganggap hal tersebut adalah suatu yang harus dijaga.

Teknik pengambilan gambar pada scene ini menggunakan teknik close up untuk menciptakan kedekatan dengan para penonton. Simbol ini jelas sengaja digunakan oleh Ke\$ha dalam video klipnya untuk diperkenalkan kepada para penonton atau fansnya agar mereka ingat dan terbayang selalu akan simbol tersebut. Segitiga dalam scene tersebut dibentuk dengan cara membentuk garis yang ditarik sehingga terbentuk segitiga. Bagian background dibentuk seperti bling-bling yang menyerupai berlian. Simbol segitiga dalam scene ini terlihat berkilau, hal ini bertujuan untuk menarik perhatian para penonton agar mereka memusatkan pandangannya ke arah simbol tersebut. Video klip ini mencoba untuk mendoktrin pemikiran masyarakat dengan cara menyisipkan simbol-simbol berbasis okultisme seperti ini. Dengan begitu, mereka yang tidak memahami arti simbol tersebut akan mengingat bahkan memakai atribut dari kelompok tersebut.

Pencahayaan di dalam scene ini juga terlihat gelap dengan background yang berwarna gelap. Warna gelap sangat dominan di dalam video klip ini termasuk ke dalam scene ini. Warna hitam di dalam kelompok Illuminati dianggap sebagai putih begitu juga sebaliknya. Hal tersebut menunjukkan bahwa apa yang mereka pikirkan sebenarnya berbanding terbalik dengan apa yang ada di dunia sebenarnya. Hitam menurut mereka adalah kebaikan. Bisa ditarik kesimpulan bahwa background dari scene ini menurut kelompok Illuminati adalah suatu kebaikan yang sama seperti warna putih. Bila dihubungkan dengan arti warna, hitam 
melambangkan adanya misteri, kekuatan, kemewahan bahkan magis. Makna dari warna tersebut warna hitam dalam scene ini dianggap sebagai suatu yang suci, murni, tak berdosa.

Editing yang digunakan di dalam scene ini adalah dramatic tension yang menekankan pada pemusatan perhatian yang diarahkan kepada para penonton. Dilihat dari scene sebelumnya, scene ini muncul ketika Ke\$ha dan para pengikutnya memasuki Gereja dengan cara mendobrak Gereja tersebut. Lalu scene dengan simbol segitiga ini menjadi salah satu simbol transisi yang diperlihatkan untuk menambah kesan dramatis dalam video klip ini.

Adegan ini menceritakan Ke\$ha bersama keempat pengikutnya berada di dalam altar sebuah Gereja dengan background simbol pentagram dalam bentuk sinar.

Simbol pentagram menjadi sangat eye catching karena letaknya yang berada di tengahtengah altar Gereja dan bersinar.

Pengambilan gambar secara long shot, ingin memperlihatkan keseluruhan setting dalam scene ini, sehingga dapat memperlihatkan interaksi antara Ke\$ha dengan simbol pentagram. Gerakan yang dilakukan oleh Ke\$ha diambil melalui sudut pengambilan gambar secara eye level. Hal ini dilakukan agar para penonton dapat melihat lebih jelas apa yang sedang dilakukan oleh Ke\$ha melalui sudut pengambilan gambar secara normal di dalam ruangan tersebut.

Pencahayaan di dalam Gereja tersebut menggunakan sumber cahaya fill light yang berasal dari pilar-pilar yang berguna untuk mengurangi jatuhnya bayangan di sisi kanan dan kiri ruangan. Simbol pentagram dalam scene tersebut juga adalah sebuah cahaya yang dipancarkan. Cahaya dalam pentagram tersebut menjadi backlight yang letaknya berada dibelakang Ke\$ha dan berfungsi untuk menghilangkan cahaya yang jatuh di bagian belakang objek. Suasana di sekitar altar Gereja cukup gelap dan mencekam. Sutradara selalu memasukkan unsur warna hitam dalam setting nya sebagai simbol kekuatan mistis disetiap scene nya. Suasana dalam Gereja tersebut merupakan setting asli yang memperlihatkan isi dari sebuah Gereja. Cahaya pilar yang digunakan adalah setting tambahan. Hal ini digunakan untuk memberikan efek "tersinari". "Tersinari” disini dapat disamakan dengan arti dari Illuminati sendiri yaitu "Yang Tersinari" yang mengarah kepada Lucifer. Hal ini berguna untuk memberikan kesan bahwa simbol tersebut menjadi titik pusat penghormatan dalam scene ini.

Editing yang digunakan dalam scene ini pun menggunakan teknik pacing scene yang berguna untuk mengikuti irama atau ketukan lagu. Scene sebelumnya menceritakan ketika Ke\$ha berada di tengah altar sedang duduk 
bersama dengan keempat pengikut wanitanya.

Dalam scene tersebut, Ke\$ha mengikuti lirik lagu pada bagian "when we tearing it up", lalu disambung dengan scene kelima ini agar memberikan kesan adanya dramatisasi bahwa ia mengangkat kedua tangannya merujuk kepada simbol pentagram pada saat ia menyanyikan lirik lagu "you know".

Simbol Illuminati pada scene ini dimaknai sebagai simbol yang dihormati bagaikan Tuhan yang disembah oleh umatnya, dengan segala kekuatan dan misteri yang berada di dalamnya.

Secara visual, Scene terakhir, yaitu adegan Ke\$ha berjalan keluar dari Gereja dan ia menyerahkan karena telah dikepung oleh sekawanan polisi bersenjata. Adegan ini ingin menyampaikan kepada penonton bahwa walaupun Ke\$ha meyerahkan diri, namun simbol Illuminati ini tetap 'berada' di dirinya, menyatu dalam konsep diri hingga menjadi sebuah ideologi.

Sekawanan polisi dapat dimaknai sebagai kondisi masyarakat saat ini yang masih menentang ajaran ini, namun demikian ajaran ini digambarkan tetap menjadi pegangan hidup bagi para penganutnya, karena ajaran Illumninati telah merasuk kedalam diri mereka dan telah menjadi ideologi mereka.

\section{SIMPULAN}

Dalam video klip “Die Young” ini, level realitas menunjukkan bahwa Ke\$ha mencoba untuk mendekatkan diri pada penonton dengan memperlihatkan bentuk-bentuk simbol tersebut, ia mencoba untuk mengagungkan dan meninggikan simbol-simbol iluminati yang ada di video klip ini. Pada level representasi, simbol Illuminati digambarkan melalui penonjolanpenonjolan pada simbol iluminati agar lebih eye catchy, sehingga penonton bias merasakan kedekatan, dengan cara memunculkan simbol Illuminati sebagai bagian dari kekuatan, misteri dan keseriusan dalam kehidupan manusia. Sedangkan pada level ideologi, dapat disimpulkan bahwa kebebasan gaya hidup, sensualitas, anti kemapanan menjadi hak dari setiap individu dan mereka berhak untuk melakukan apapun yang mereka inginkan.

\section{DAFTAR PUSTAKA}

Dameria, A. (2007). Color basic: panduan dasar Warna untuk Desainer dan Industri Grafika. Jakarta: Link \& Match Graphic.

Ezza, M. A. (2014). Simbol-simbol illuminati di Arab Saudi. Jakarta: Pyramid.

Hall, S. (1997). Representation: cultural representation and signifying practices. Thousand Oaks: Sage Publications, Inc. http://www.crossroad.to/Books/symbols1.html. (2015, April 12). Retrieved from Symbols and Their Meaning: http://www.crossroad. to/Books/symbols1.html

Indriani, S. S., \& Prasanti, D. (2017). Makna gambar 3 biri-biri dan kotak pada film 'the little prince'. ProTVF: Jurnal Kajian Televisi Dan Film, 1(1), 77-88. 
Makow, H. (2012). Illuminati: dunia dalam genggaman perkumpulan setan. Jakarta: Ufuk Publishing House.

Marrs, T. (2013). Codex magica: tanda rahasia, simbol misterius dan kode tersembunyi illuminati. Jakarta: Change.
Moon, P. (2010, July 2010). 8 Historic Symbols That Mean The Opposite of What You Think. Retrieved from Cracked: https:// www.cracked.com/article_18606_8historic-symbols-that-mean-opposite- $\% 20$ what-you-think.html 